Gut, 1976, 17, 119-121

\title{
Hepatitis-B surface antigen and cirrhosis in Iraq
}

\author{
E. H. BOXALL, ${ }^{1}$ T. H. FLEWETT, A. PATON, AND S. W. RASSAM
}

From the Regional Virus Laboratory, East Birmingham Hospital, Birmingham, and Department of Medicine, Medical City, Baghdad, Iraq

SUMMARY Hepatitis-B surface antigen was found in $58 \%$ of 64 patients with cirrhosis in Iraq using counter immunoelectrophoresis (CIE), radioimmunoassay (RIA), and three commercial haemagglutination tests-Auscell (Abbott Laboratories), Hepatest (Wellcome Reagents Ltd.), and Hepanosticon (Organon Teknika). CIE detected about half as many positives as the other methods; RIA was the most sensitive. The number of positive reactions was much higher than in any previously reported series of patients with cirrhosis and seven times higher than in a normal hospital control population.

Cirrhosis is believed to be common in developing countries; in most cases the cause is unknown. Given the high incidence of hepatitis-B surface antigen $\left(\mathrm{HB}_{\mathrm{s}} \mathrm{Ag}\right)$ in such populations, it is obvious that the hepatitis virus ought to be considered as a possible aetiological agent. During a clinicopathological study of cirrhosis in Iraq, specimens of blood were therefore collected in order to test for the presence of $\mathrm{HB}_{\mathrm{s}} \mathrm{Ag}$. They were tested by five different techniques, as part of an investigation of the sensitivity of available methods, and the high proportion of positive results compared with a control group prompts this report.

\section{Methods}

Sera were obtained from 64 patients with cirrhosis admitted to Medical City, Baghdad. The diagnosis was confirmed by liver biopsy in 47 patients, the remainder being accepted on the usual clinical criteria, because it was not possible to carry out a biopsy on account of gross fluid retention or a bleeding tendency. Six patients were judged on clinicopathological grounds to be suffering from alcoholic cirrhosis and four from chronic active hepatitis, while the remaining 54 were labelled cryptogenic. Ninety-one sera were obtained from control patients without liver disease; these were matched for age and sex with the cirrhosis group.

Sera were stored at $-20{ }^{\circ} \mathrm{C}$. The following tests were employed for detection of $\mathrm{HB}_{\mathrm{s}} \mathrm{Ag}$, without

\footnotetext{
${ }^{1}$ Address for reprint requests: E.H.B., Regional Virus Laboratory, East Birmingham Hospital, Birmingham B9 5ST

Received for publication 10 November 1975
}

prior knowledge of the clinical diagnosis or origin of the sample.

1. Counter-immunoelectrophoresis (CIE) using a low voltage technique employing $0.9 \%$ agarose in $0.05 \mathrm{M}$-sodium barbitone at $\mathrm{pH} 8.6$ and a current of $20 \mathrm{~mA}$ for 75 minutes. Two antisera were used: a monkey antiserum with predominantly ay specificity, and a human antiserum with ad specificity.

2. Solid phase radioimmunoassay (RIA) using the Ausria II-125 diagnostic kit (Abbott Laboratories). Sensitivity has been improved by providing a greater surface area for the attachment of protein by using a small plastic bead about $6 \mathrm{~mm}$ in diameter as the solid phase. The bead is coated with guineapig antibody to $\mathrm{HB}_{\mathrm{s}} \mathrm{Ag}$. Specificity has also been improved by using human ${ }^{125}$ I-labelled hepatitis-B surface antibody $\left(\mathrm{HB}_{\mathrm{s}} \mathrm{Ab}\right)$. Radioactivity counts of test samples are compared with those of positive and negative controls, and the test is valid if the positive control is greater than five times the negative control. Positive results are confirmed by demonstrating neutralization by a specific human antiserum.

3. Three distinct direct haemagglutination tests based on the principles of reversed passive haemagglutination (Juji and Yokochi, 1969):

a. Auscell (Abbott Laboratories) using specially prepared, stabilized human erythrocytes sensitized with guinea-pig antibody to $\mathrm{HB}_{\mathrm{s}} \mathrm{Ag}$. The test is carried out in disposable rigid V-bottomed Microtitre plates (Cooke Instruments Ltd.), and agglutination patterns read after two hours' incubation at room temperature. Samples are screened at a dilution of 1 in 16, and positive and negative controls are included. Care is needed by the inexperienced in interpreting the results. Positives are 
confirmed by a neutralization test using human $\mathrm{HB}_{\mathrm{s}} \mathrm{Ab}$.

b. Hepatest (Wellcome Reagents Ltd.) using formalinized, tanned, turkey erythrocytes coated with horse antibody to $\mathrm{HB}_{\mathbf{s}} \mathrm{Ag}$ (test cells) or normal horse IgG (control cells) (Cayzer et al., 1974; Chrystie et al., 1974). Microtitre U-bottomed plates are used and, as nucleated erythrocytes settle quickly, the results can be read after 30 minutes' incubation at room temperature. Samples are screened at a dilution of 1 in 10.

c. Hepanosticon (Organon Teknika) using sensitized sheep erythrocytes (Reesink et al., 1973). Only $10 \mu \mathrm{l}$ serum or plasma is required and this is added to a $500 \mu \mathrm{l}$ volume of cell suspension in disposable glass sedimentation tubes. The pattern of agglutination is read from below, using a special rack with angled mirror, after three hours' incubation at room temperature. Positives are retested after absorption with a specially provided absorbent.

\section{Results}

\section{CIRRHOSIS GROUP}

There were 51 men and 13 women, ranging in age from 18 to 70 years with a mean age of 44 years. $\mathrm{HB}_{\mathrm{s}} \mathrm{Ag}$ was detected by $\mathrm{CIE}$ in 17 patients $(26.5 \%)$, but the number of positives was doubled by the use of the other methods, RIA and Auscell being the most sensitive (Table). Although Hepatest was the least sensitive in this series, tests on a British population (E.H.B., unpublished) showed its sensitivity to be equivalent to that of Hepanosticon. The overall incidence of positive tests was $37(58 \%)$. All sera positive by CIE were positive by RIA and the three agglutination tests. Only two sera were positive by RIA alone, but these had very low 'count ratios' (counts in test/counts in negative control) and probably contained $\mathrm{HB}_{\mathrm{s}} \mathrm{Ag}$ below the level detectable by the haemagglutination tests.

$\mathrm{HB}_{\mathrm{S}} \mathrm{Ag}$ was found in 33 of the 51 males but in only four of the 13 females. It was not detected in any of the six alcoholics but was present in

\begin{tabular}{|c|c|c|c|c|}
\hline & \multicolumn{2}{|c|}{ Cirrhosis } & \multicolumn{2}{|l|}{ Controls } \\
\hline & $\begin{array}{l}\text { No. } \\
\text { positive }\end{array}$ & $\begin{array}{l}\% \\
\text { positive }\end{array}$ & $\begin{array}{l}\text { No. } \\
\text { positive }\end{array}$ & $\begin{array}{l}\% \\
\text { positive }\end{array}$ \\
\hline $\begin{array}{l}\text { Counter immuno- } \\
\text { electrophoresis } \\
\text { Auscell } \\
\text { Hepatest } \\
\text { Hepanosticon } \\
\text { Radioimmunoassay }\end{array}$ & $\begin{array}{l}17 \\
36 \\
31 \\
34 \\
37\end{array}$ & $\begin{array}{l}26 \cdot 5 \\
56 \cdot 5 \\
48 \cdot 5 \\
53 \\
58\end{array}$ & $\begin{array}{l}3 \\
5 \\
5 \\
4 \\
8\end{array}$ & $\begin{array}{l}3 \cdot 3 \\
5 \cdot 5 \\
5 \cdot 5 \\
4 \cdot 4 \\
8 \cdot 8\end{array}$ \\
\hline Totals & \multicolumn{2}{|l|}{64} & \multicolumn{2}{|l|}{91} \\
\hline
\end{tabular}

Table Comparison of tests for hepatitis-B surface antigen in patients with cirrhosis and hospital controls two of the four patients with chronic active hepatitis (both males). Of 40 patients with cryptogenic cirrhosis in whom biopsies were available, 24 sera were positive and 16 negative. Although we cannot be certain, we believe that the activity of the cirrhosis was greater, and post-necrotic changes more common, in the antigen positive group.

\section{HOSPITAL CONTROLS}

$\mathrm{HB}_{\mathrm{s}} \mathrm{Ag}$ was detected by $\mathrm{CIE}$ in only three patients $(3.3 \%)$, the number of positives being increased using the more sensitive tests, RIA again being the most sensitive. There was very little difference in the sensitivity of the three haemagglutination tests, Hepanosticon missed two sera which were positive by Auscell and Hepatest, and similarly Hepatest missed one positive which was picked up by the other two haemagglutination tests. The overall incidence of positive tests was eight $(8.8 \%)$, only two of which were positive by RIA alone.

\section{Discussion}

An overall incidence of $58 \%$ positive $\mathrm{HB}_{\mathrm{s}} \mathrm{Ag}$ in a group of patients with cirrhosis in Iraq is very much higher than has been reported from any other part of the world. A figure of $26.5 \%$ was found on testing by CIE alone and this may be compared with the findings of Anthony et al. (1972) who reported $32.9 \%$ positives in a group of cirrhotics from Uganda using counter electrophoresis and complement fixation, and of Bagshawe et al. (1971) from Kenya, who found a positive rate of $20.5 \%$ with gel diffusion. Reed et al. (1973) using radioimmunoassay, found $26 \%$ positives in a small number of patients with cryptogenic cirrhosis but these included both British and foreign nationals. The number of positive reactions in cirrhotics from the Far East tested by counter immunoelectrophoresis appeared to be far lower (Whittingham et al. 1973).

The more sensitive tests for $\mathrm{HB}_{\mathrm{s}} \mathrm{Ag}$ detected approximately twice as many positives as CIE. The prevalence rate among the hospital controls $13.3 \%$ by CIE) agrees closely with a figure of $3.6 \%$ positives among blood donors in Iraq by counter immunoelectrophoresis (Skinhøj and Al-Kassab, 1973). Even by the most sensitive technique ( $8.8 \%$ by RIA), this value is nowhere near the figure found in patients with cirrhosis.

Using the same group of tests in 66 patients with cirrhosis in Birmingham we found $7.6 \%$ positive by RIA and $3 \%$ by the other four methods (unpublished observations). Since the majority were alcoholic (Jain et al., 1973), it will take time to test enough patients with cryptogenic cirrhosis, but it is most 
unlikely that the frequency of $\mathrm{HB}_{\mathrm{s}} \mathrm{Ag}$ will be as high as in Iraq.

The significance of the present findings remains to be determined. The majority $(88 \%)$ of the small number of sera tested belonged to the ay subtype, which is thought to predominate in the Middle East, and was found in all the samples tested by Skinhøj and $\mathrm{Al}-\mathrm{Kassab}$ (1973). Further subtyping is being carried out by Dr G. Le Bouvier and his colleagues.

Although the incidence of $\mathrm{HB}_{\mathrm{s}} \mathrm{Ag}$ in the Iraqi patients with cirrhosis is far higher than in the general population in Iraq and in Great Britain, it cannot yet be assumed that the presence of antigen necessarily indicates that hepatitis-B virus is the cause of the disease. However, a detailed survey of the patients seen in Baghdad (Rassam and Paton, to be published) has so far failed to reveal any aetiological factor, other than alcohol in a few; in particular, malnutrition and bilharziasis could be excluded as important causes. Moreover, cirrhosis differs in at least two other important respects from that seen in the West: haematological changes usually designated as 'hypersplenism' are twice as frequent and the $\gamma$-globulin fraction of the plasma proteins is often markedly raised. The possibility of an abnormal immune response is at present under investigation. If it could be shown that nearly $60 \%$ of cirrhosis in Iraq, and other countries in the Middle East and Africa, is caused by the hepatitis virus, this would represent a significant advance in understanding a common disease whose aetiology is at present obscure.

We thank Abbott Laboratories, Organon Teknika and Wellcome Reagents Ltd., for generous supplies of test materials.

\section{References}

Anthony, P. P., Vogel, C. L., Sadikali, F., Barker, L. F., and Peterson, M. R. (1972). Hepatitis-associated antigen and antibody in Uganda: correlation of serological testing with histopathology. British Medical Journal, 1, 403-406.

Bagshawe, A. F., Parker, A. M., and Jindani, A. (1971). Hepatitis-associated antigen in liver disease in Kenya. British Medical Journal, 1, 88-89.

Cayzer, I., Dane, D. S., Cameron, C. H., and Denning, J. V. (1974). A rapid haemagglutination test for hepatitis-B antigen. Lancet, 1, 947-949.

Chrystie, I. L., Islam, M. N., Banatvala, J. E., and Cayzer, I. (1974). Clinical evaluation of the turkey-erythrocyte passive-haemagglutination test for hepatitis-B surface antigen. Lancet, 1, 1193-1194.

Jain, S., Paton, A., and Wansbrough-Jones, M. H. (1973). Cirrhosis in Birmingham. Midland Medical Review, 9, 13-16.

Juji, T., and Yokochi, T. (1969). Haemagglutination technique with erythrocytes coated with specific antibody for detection of Australia antigen. Japanese Journal of Experimental Medicine, 39, 615-623.

Reed, W. D., Eddleston, A. L. W. F., Stern, R. B., Williams, R., Zuckerman, A. J., Bowes, A., and Earl, P. M. (1973). Detection of hepatitis-B antigen by radio-immuneassay in chronic liver disease and hepatocellular carcinoma in Great Britain. Lancet, 2, 690-694.

Reesink, H. W., Duimel, W. J., and Brummelhuis, H. G. J. (1973). Evaluation of a new haemagglutination technique for the demonstration of hepatitis-B antigen. Lancet, 2 , 1351-1353.

Skinhøj, P., and Al-Kassab, S. (1973). Hepatitis-B antigen in Iraq. Lancet, 2, 1269.

Whittingham, S., Mackay, I. R., Thanabalasundrum, R. S., Chuttani, H. K., Manjuran, R., Seah, C. S., Yu, M., and Viranuvatti, V. (1973). Chronic liver disease: differences in autoimmune serological reactions between Australians and Asians. British Medical Journal, 4, 517-519. 